\title{
家兔筋肉蛋白のAmino 酸組成に就て
}

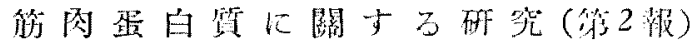

融主誠

(東京帝國大學農學部農憼化學教空)

畩和 16 年 7 月 28 日浽理

粕言

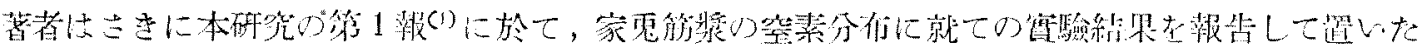

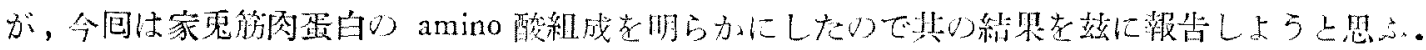

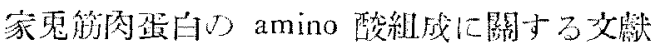

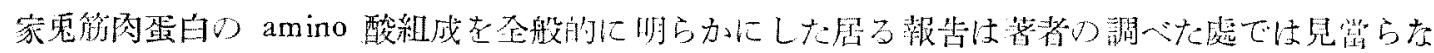
$n$.

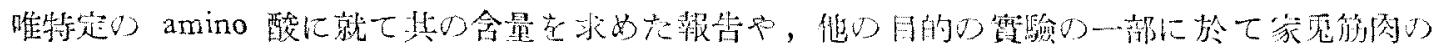

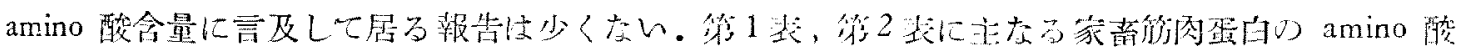
含量及䇪菜分布（van Slyke 法に上る）在比較りため結果だけ在抄記する。

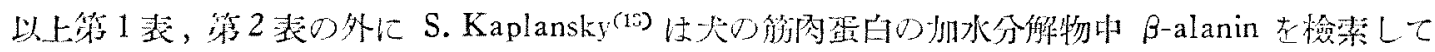

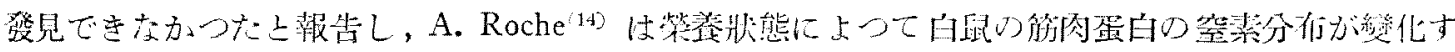
ると乖べて居る。

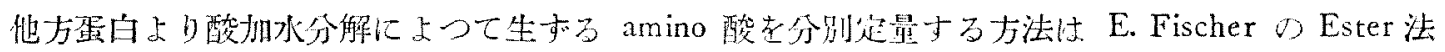

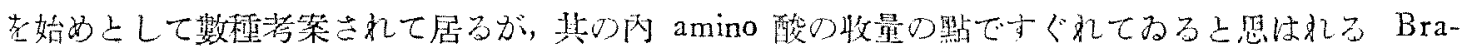

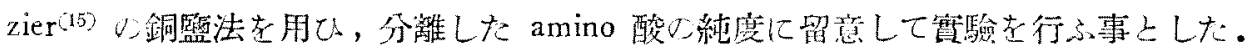

\section{I) 家霓筋闪蛋白の調製}

\section{實 驗 の 部}

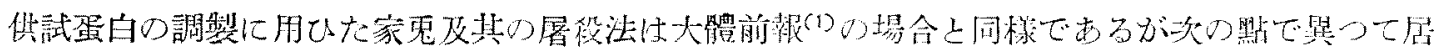

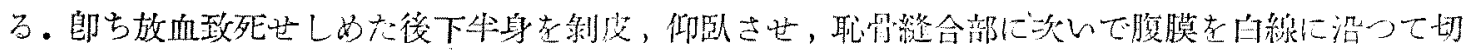

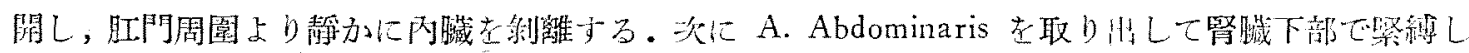

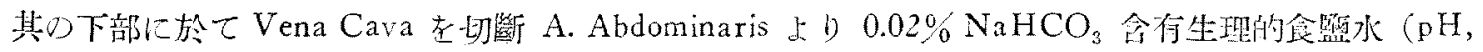

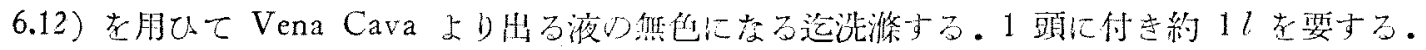

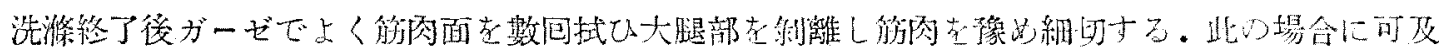

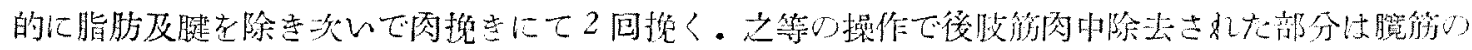

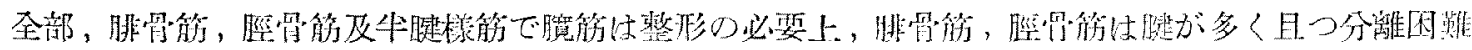

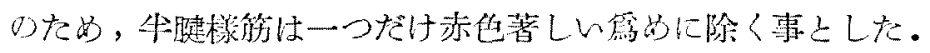

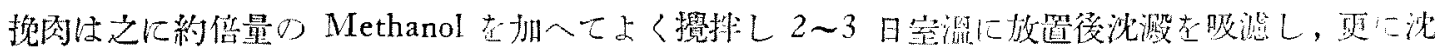

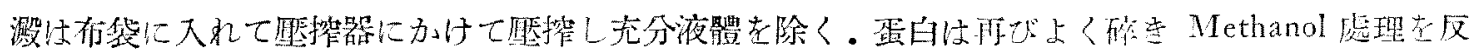
復するこ上計 3 回後薄く擴げて宾湿で揮散させて後大型固體

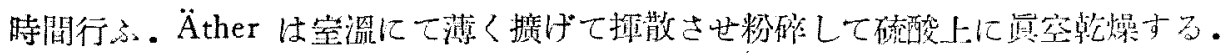




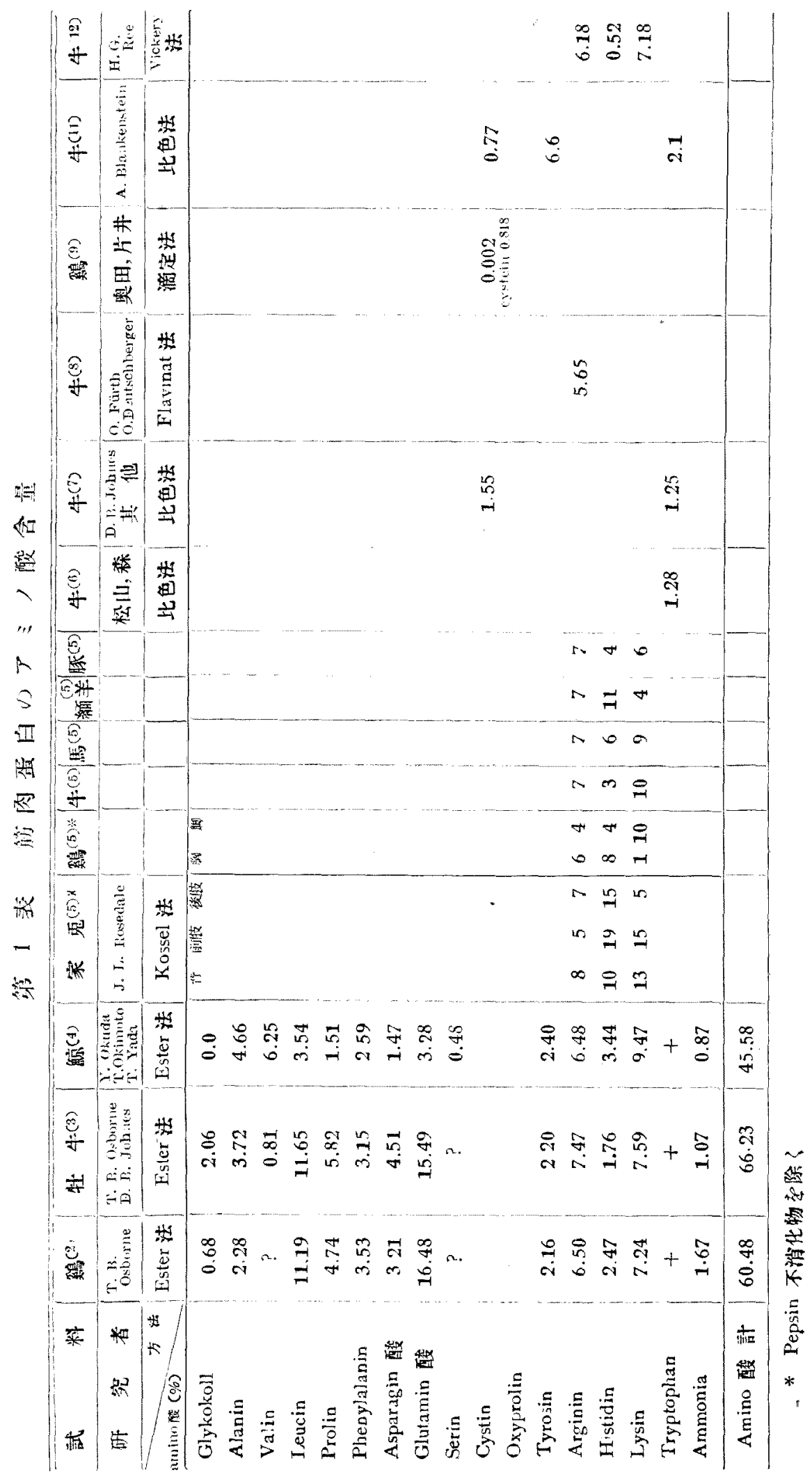




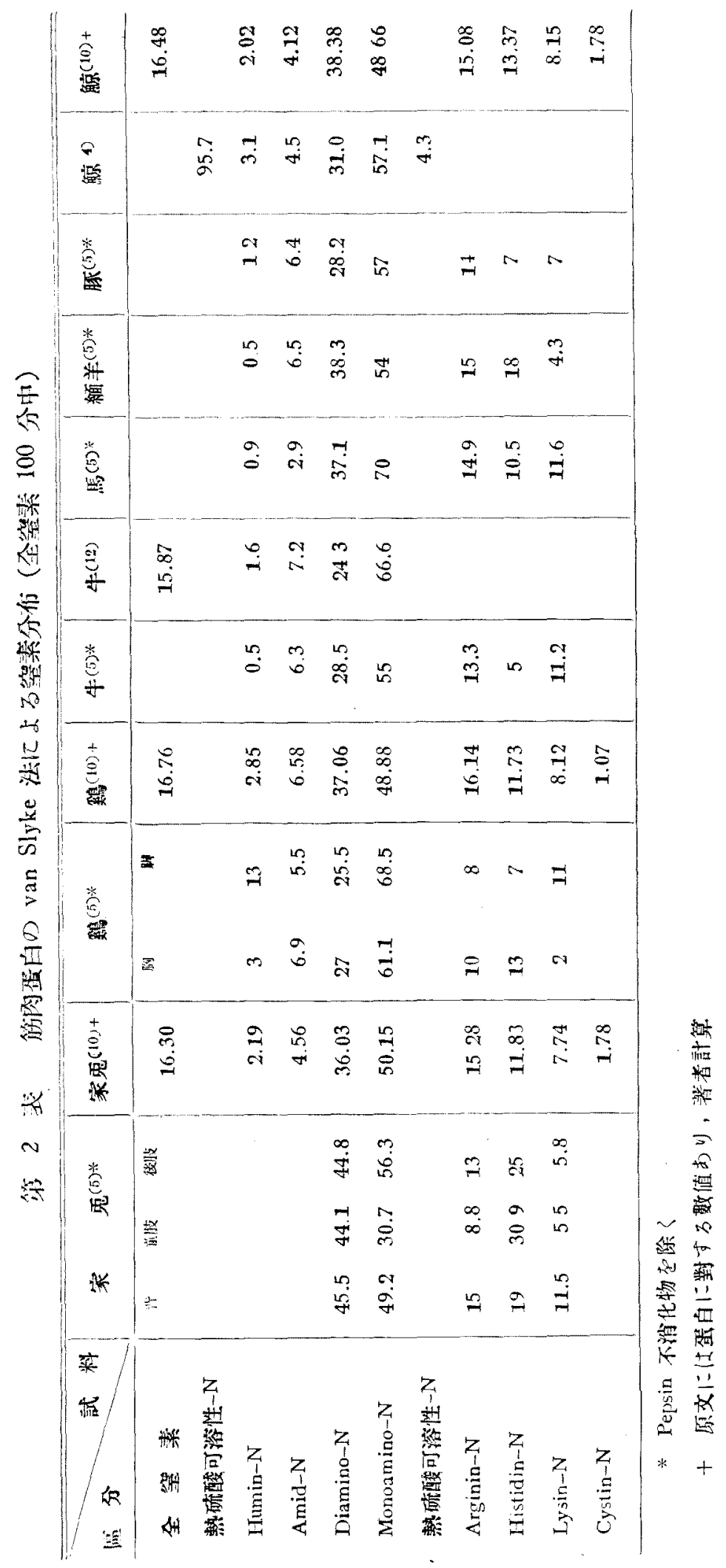




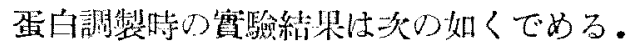

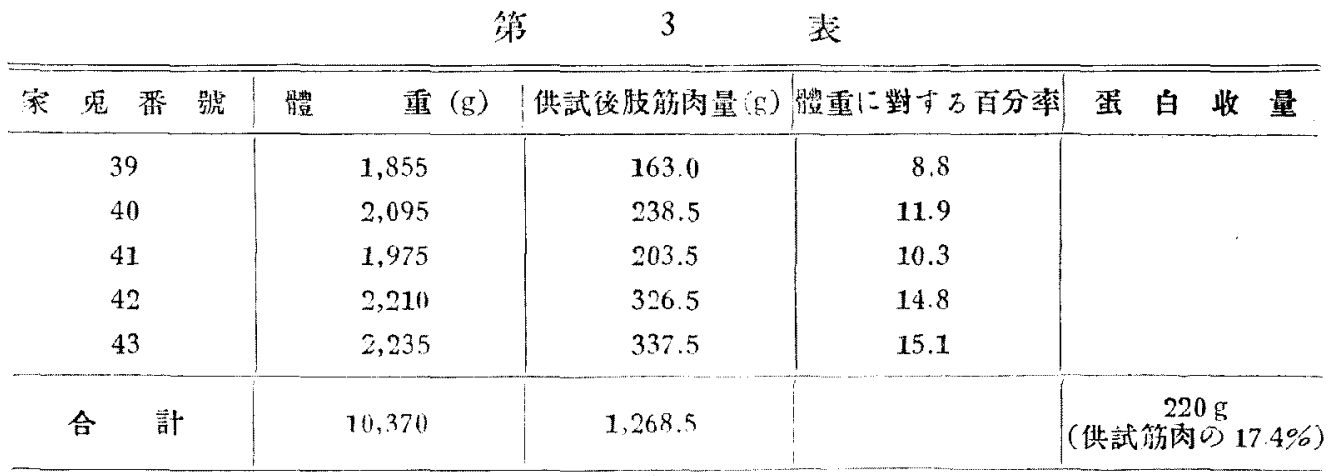

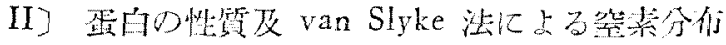

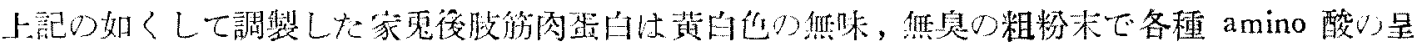
巴反應，Biuret, Xanthoprotein, Millon, Diazo-, Adamkiewicz, Neubauer 及 Rohde, 坂口の諸反 應及 Molisch 反應何丸も陽性である。

分析 絬 果

\begin{tabular}{|c|c|c|c|c|c|}
\hline & 供試蛋白 100 分中 & 然水蛋白 100 分中 & & 供試蛋白 100 分中 & 無水蛋白 100 分中 \\
\hline 水分 + & 12.80 & & 硫黃(16) & 1.07 & 1.22 \\
\hline 贯素 & 14.08 & 16.12 & 燐 & + & + \\
\hline 裑分 & 1.35 & $\mathbf{1 . 5 5}$ & & & \\
\hline
\end{tabular}

茲 K jeldahl 法, $+110^{\circ}$ 乾燥恒量さす

空素分倠（van Slyke 法）

試料： $1.45 \mathrm{~g}, 2.00 \mathrm{~g}$ 在用し! van Slyke 法儿上つて空素分有在定めて。加水分解液の amino- $\mathrm{N}$ 索定量した結果，加水分解は 12 時間で旮分であつた。

\begin{tabular}{l|r}
\hline & 全等素 100 分中 \\
\hline $20 \% \mathrm{HCl}$ 不溶-N & 0.61 \\
$20 \% \mathrm{HCl}$ 可溶-N & 99.36 \\
Amid-N & 689 \\
Ilumin-N & 1.02 \\
Diamino-N & 28.46 \\
Arginin-N & 12.72 \\
Histidin-N & 3.30 \\
Lysin-N & 10.68 \\
Cystin-N & 1.76 \\
Monoamino-N & 37.97 \\
非 amino-N & 23.78 \\
\hline \multicolumn{1}{c}{ 計 } & 99.74 \\
\hline
\end{tabular}

Tryptophan 及 Tyrosin 含量

試料： $0.3993 \mathrm{~g}, 0.5157 \mathrm{~g}, 0.5224 \mathrm{~g}$ 老之り，FolinMarenzi 法-Lugg 改良法 ${ }^{(17)}$ によ Tyrosin (I) $0.1061 \mathrm{~g}$ 而 Tryptophan (II) $0.0832 \mathrm{~g}$ 老夫飞 $0.1 \mathrm{~N}$ $\mathrm{H}_{2} \mathrm{SO}_{4}$ 及水に溶加して $100 \mathrm{cc}$ となし，(I)上り $2 \mathrm{cc}$, (II) より $1 \mathrm{cc}$ 老とつて混合し標集として定量 した.

\begin{tabular}{l|c|c}
\hline \hline & 供試蛋白 100 分中 & 乾物 $\mathbf{1 0 0}$ 分中 \\
\hline Tyro in & 3.57 & 4.29 \\
Tryptophan & 1.06 & 1.84 \\
\hline
\end{tabular}

III] Amino 酸の分離

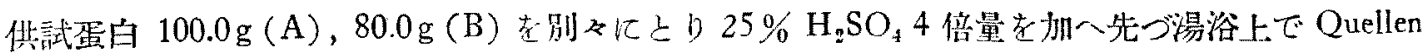




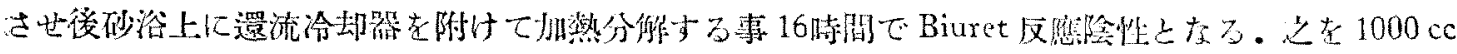

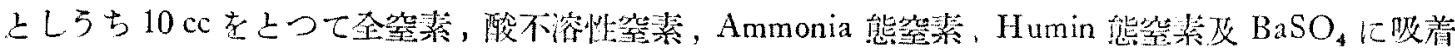

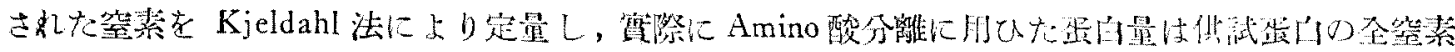

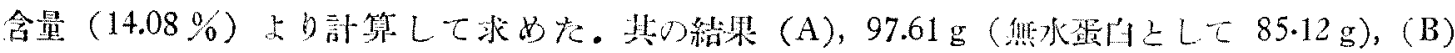

\begin{tabular}{|c|c|c|c|c|c|c|c|c|c|}
\hline 全 & 政 & 素 & $\frac{11.0092}{\left(\mathrm{~g}^{\prime}\right)}$ & 全害䇣 100 分中 & 全 & 勧 & 素 & $\begin{array}{c}11.0092 \\
(\mathrm{~g})\end{array}$ & 全第素 100 分中 \\
\hline \multirow{2}{*}{\multicolumn{3}{|c|}{ 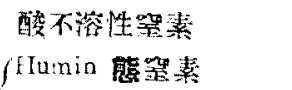 }} & 0.3930 & 3.57 & \multirow{4}{*}{\multicolumn{3}{|c|}{ 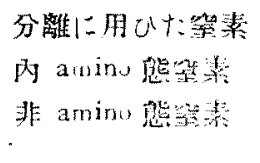 }} & 9.7277 & 88.33 \\
\hline & & & 0.5052 & 4.56 & & & & 61170 & 55.56 \\
\hline \multirow{2}{*}{\multicolumn{3}{|c|}{ 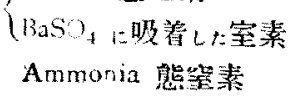 }} & 0.3743 & 3.40 & & & & 3.6037 & 32.77 \\
\hline & & & 0.5174 & 470 & & & & & \\
\hline
\end{tabular}

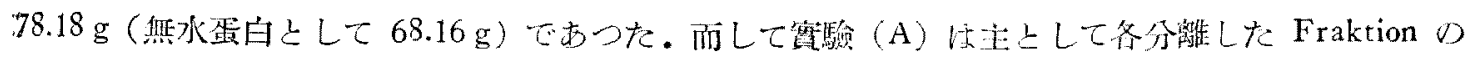

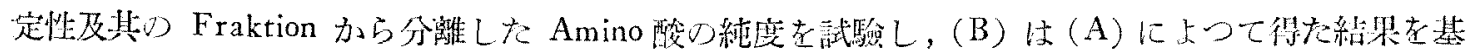

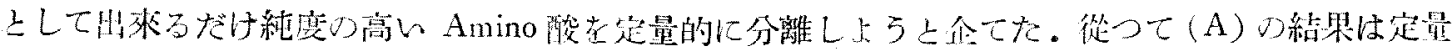

A] 水不溶性銅籃

\begin{tabular}{|c|c|c|c|}
\hline & & 全箐素100分中 & 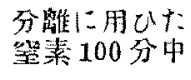 \\
\hline 全 䌑 素 & $1.0096 \mathrm{~g}$ & 9.18 & 10.37 \\
\hline 稀喃酸不溶性临素 & 0.0904 & 0.82 & 0.93 \\
\hline ' uS に昅諸にた窒素 & 0.1118 & 1.01 & 1.15 \\
\hline Amino 酸分踓に用ひた究素 & 0.8074 & 7.33 & 8.28 \\
\hline 內 Amino 態 & 0.7508 & 6.82 & 7.71 \\
\hline 非 Amino 䳆 & 0.0566 & 0.51 & 0.57 \\
\hline Asparagin 酸温分 & 0.1472 & 1.35 & 1.51 \\
\hline Leucin 區分 & 0.4892 & 4.44 & 5.01 \\
\hline Phenylalanin 區分 & 0.1565 & 142 & 1.60 \\
\hline 損失 & 00148 & 0.13 & 0.16 \\
\hline
\end{tabular}

Amino 酸 收 量

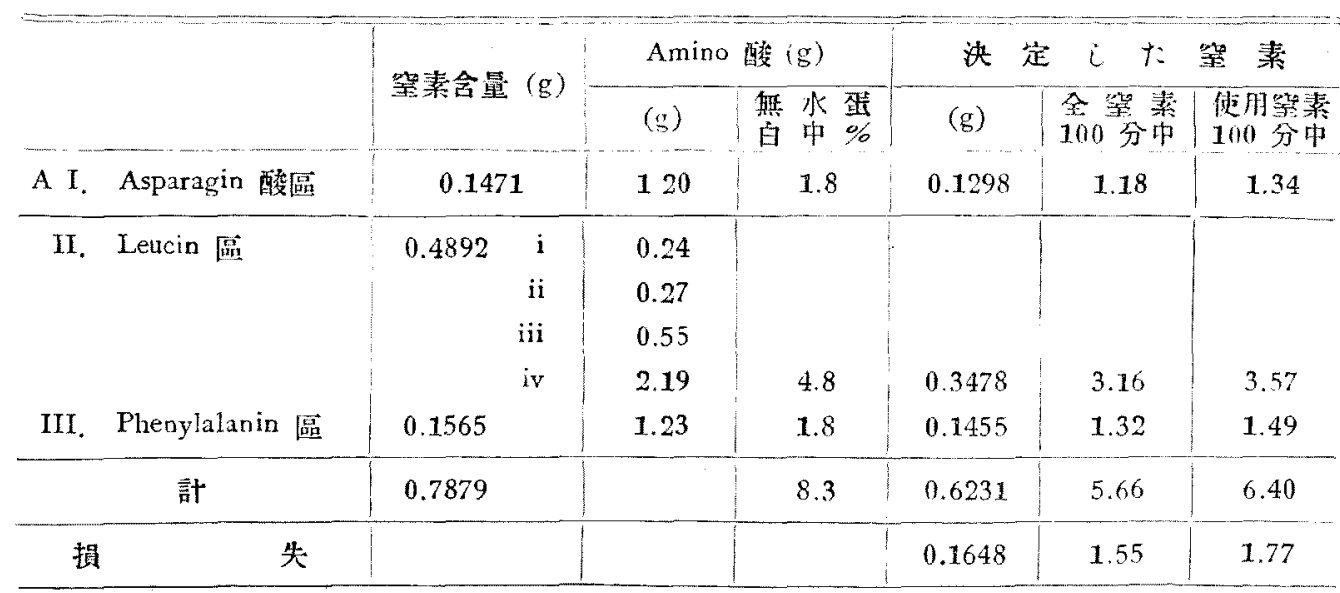




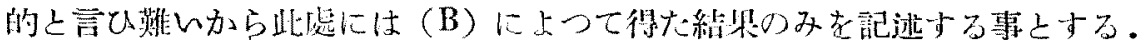

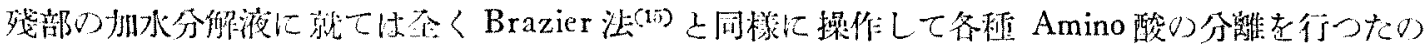

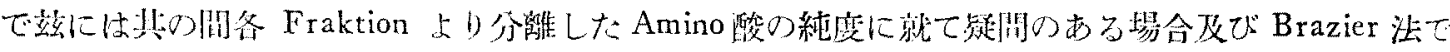

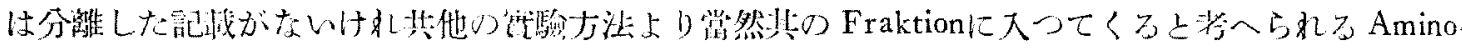

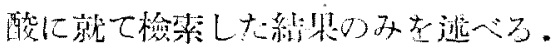

\section{A I. Asparagin 酸据}

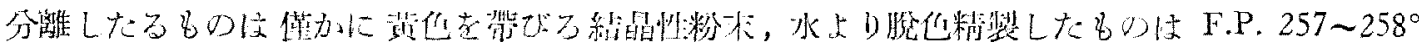

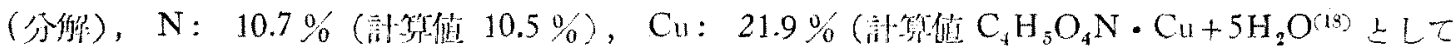
$22.3 \%)$

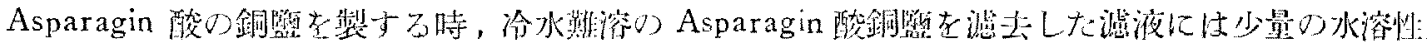

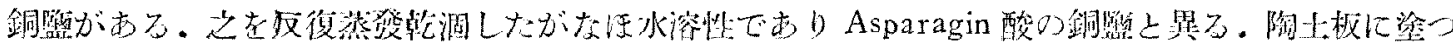

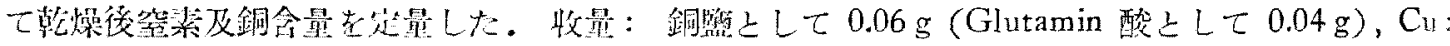

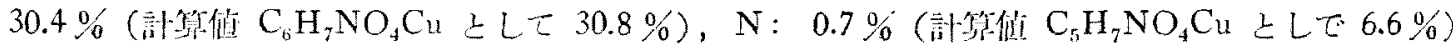

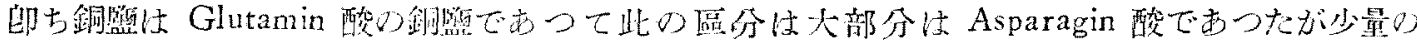
Glutamin 酸の混入して后子事索認めた。

\section{A II. Leucin 區}

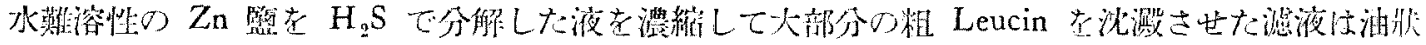

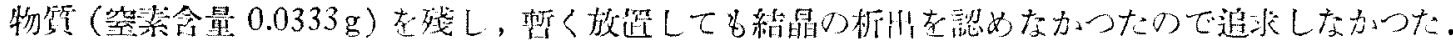

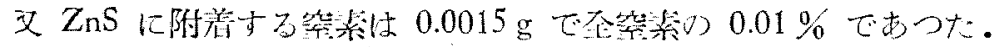

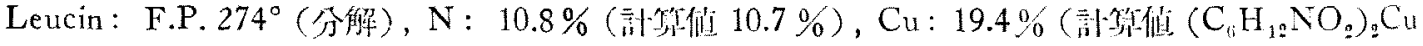
¿ $(\tau 19.6 \%)$

A III. Phenylalanin [nit

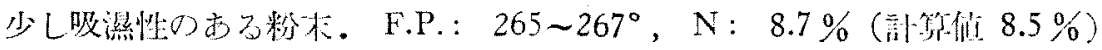

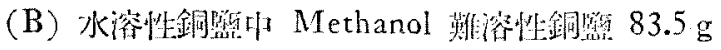

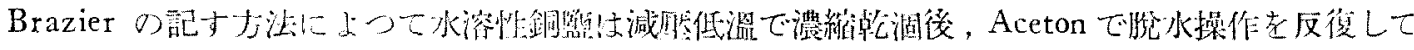

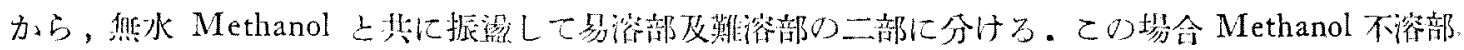

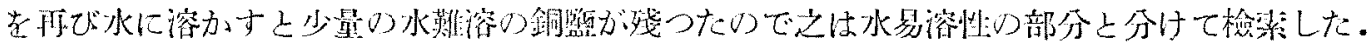

\begin{tabular}{|c|c|c|c|c|c|}
\hline & 等 & 素会 & 量 & \multirow{2}{*}{$\begin{array}{l}\text { 全学素 } \\
100 \text { 分中 }\end{array}$} & \multirow{2}{*}{$\begin{array}{l}\text { 使用窑素 } \\
100 \text { 分中 }\end{array}$} \\
\hline & 全等素 (g) & $\begin{array}{c}\text { Amino 熊嗐素 } \\
(\mathrm{g})\end{array}$ & 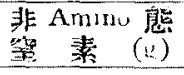 & & \\
\hline 水溶性銅艦 & 8.2491 & 5.1361 & 3.1130 & 74.93 & 84.86 \\
\hline 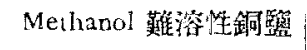 & 6.841 .8 & 4.6741 & 2.1677 & 67.14 & 70.38 \\
\hline /小難溶性銅監 & 00634 & 0.0649 & & 0.57 & 0.65 \\
\hline 〈必易溶性鉰爁 & 6.7784 & 46092 & 2.0692 & 66.57 & 69.73 \\
\hline
\end{tabular}

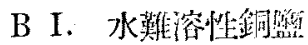

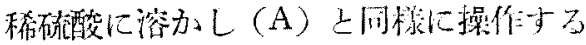

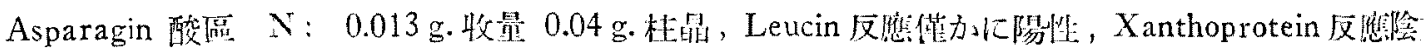

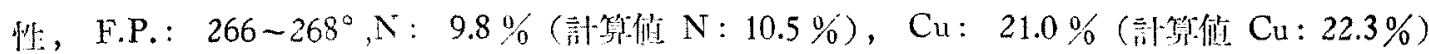




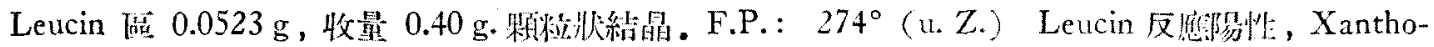

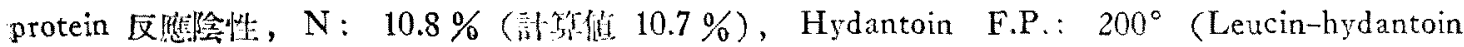
F.P. $\left.205^{\circ}\right)$

Amino 酸收量

\begin{tabular}{|c|c|c|c|c|c|c|}
\hline & \multirow{2}{*}{$\begin{array}{c}\text { 等素含 } \\
(\mathrm{g})\end{array}$} & \multicolumn{2}{|c|}{ Amino 䣮 } & \multirow{2}{*}{$\begin{array}{l}\text { 决 } \\
(\mathrm{g})\end{array}$} & \multicolumn{2}{|c|}{ i た 登 素 } \\
\hline & & (g) & $\begin{array}{l}\text { 缹水蛋 } \\
\text { 白中 } \%\end{array}$ & & $\begin{array}{l}\text { 全第䇣 } \\
100 \text { 分中 }\end{array}$ & $\begin{array}{l}\text { 使月㧼素 } \\
100 \text { 分中 }\end{array}$ \\
\hline Asparagin 酸器 & 0.0103 & 0.07 & 0.10 & 0.0074 & 0.07 & 0.08 \\
\hline Leucin fini & 0.0525 & 0.40 & 0.59 & 0.0429 & 039 & 0.44 \\
\hline 塾 & 0.0628 & & 0.69 & 0.0503 & 0.46 & 0.52 \\
\hline 賣 & & & & 0.0131 & 0.12 & 0.13 \\
\hline
\end{tabular}

B II. 水易溶性銅䧺

\begin{tabular}{|c|c|c|c|}
\hline & $(\xi)$ & 全紫素 100 分中 & 健用等装 100 分中 \\
\hline 全＼cjkstart㖕＼cjkstart素 & 6.7784 & 61.57 & 69.73 \\
\hline CuSに吸着しけ筧素 & 0.0509 & 0.46 & 0.52 \\
\hline Tyrosin 層分 & 0.1110 & 1.00 & 1.14 \\
\hline Glutamin 酸嗵分 & 1.3535 & 12.29 & 13.92 \\
\hline Diamino 酸臂分 & 3.1513 & 28.62 & 32.42 \\
\hline I Listidin 留分 & 0.2361 & 2.14 & 2.43 \\
\hline Arginin 俨分 & 1.5770 & 14.32 & 16.22 \\
\hline Jysin [盖分 & 1.3382 & 1216 & 13.77 \\
\hline Leucin 渆分 & 0.4794 & 4.35 & 4.93 \\
\hline Glykokoll 嵒分 & 0.6379 & 5.79 & 6.55 \\
\hline Alanin 曼分 & 0.3130 & 2.84 & 3.22 \\
\hline Oxyprolin 盛分 & 0.5888 & 3.35 & 6.06 \\
\hline Serin 战分 & 0.0428 & 0.35 & 0.44 \\
\hline 計 & 6.7286 & 61.09 & 69.20 \\
\hline 损 & 0.0498 & 0.48 & 0.53 \\
\hline
\end{tabular}

Amino 酸收 量

\begin{tabular}{|c|c|c|c|c|c|c|}
\hline \multirow[b]{2}{*}{ : } & \multirow{2}{*}{ 籍菉含量 } & \multicolumn{2}{|c|}{ Amino 酸 } & \multicolumn{3}{|c|}{ 決 定 $i$ 等 素 } \\
\hline & & $(g)$ & $\begin{array}{l}\text { 䑾舀 } \\
\text { 白 }\end{array}$ & (g) & $\begin{array}{l}\text { 全等 } \\
\text { Ino 素 }\end{array}$ & $\begin{array}{l}\text { 使用鳘素 } \\
100 \text { 分中 }\end{array}$ \\
\hline Tyrosin & 0.111 .0 & 1.46 & 2.1 & 0.1024 & 0.93 & 1.05 \\
\hline Glutamin 酸區 & 1.3535 & 11.21 & 16.4 & 1.0650 & 9.67 & 10.96 \\
\hline Oxy·glutamin 酸 & & 1.03 & 1.5 & 0.0886 & 0.80 & 0.91 \\
\hline I listidin & 0.2361 & 0.75 & 1.1 & 0.2033 & 1.85 & 2.09 \\
\hline Arg nin liais & 1.5770 & 4.71 & 6.9 & $1.505 \%$ & 13.68 & 16.52 \\
\hline Lysin $[\vec{b}$ & 1.3382 & 6.55 & 9.6 & 1.2786 & 11.61 & 13.15 \\
\hline Teucin 酃 & 0.4794 & 4.48 & 6.6 & 0.4794 & 4.35 & 4.93 \\
\hline 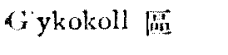 & 0.6379 & 2.89 & 4.2 & 0.5397 & 4.90 & 5.55 \\
\hline
\end{tabular}




\begin{tabular}{|c|c|c|c|c|c|c|}
\hline $\begin{array}{l}\text { Alanin 前 } \\
\text { Oxyprolin bin }\end{array}$ & $\begin{array}{l}0.3130 \\
0.5888\end{array}$ & $\begin{array}{l}1.93 \\
0.02\end{array}$ & $\begin{array}{l}2.8 \\
02\end{array}$ & $\begin{array}{l}0.3030 \\
0.0721\end{array}$ & $\begin{array}{l}2.75 \\
0.02\end{array}$ & $\begin{array}{l}3.12 \\
0.02\end{array}$ \\
\hline 竐 & 6.6349 & 35.02 & 51.4 & 5.5678 & 50.56 & 58.30 \\
\hline 强 & & & & 1.2106 & 11.00 & 12.46 \\
\hline
\end{tabular}

Tyrosin

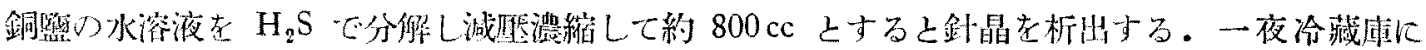

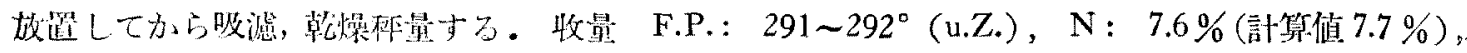

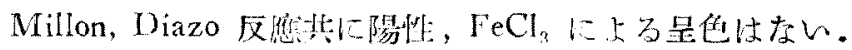

Glutamin 㜔盖

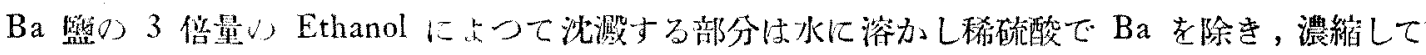

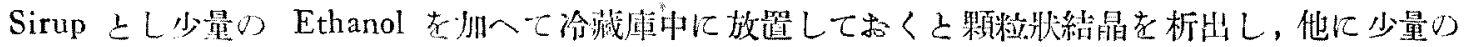

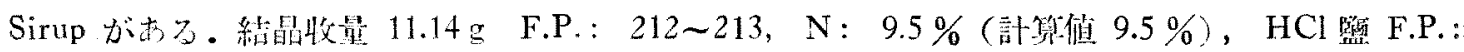

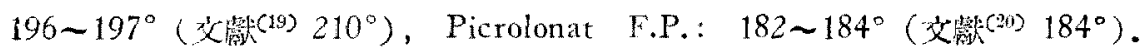

$\beta$-Oxyglutamin 酸澄明

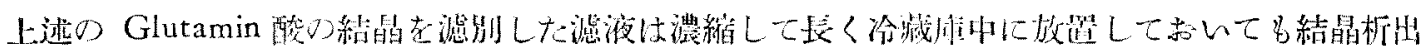

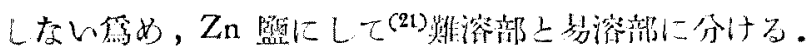

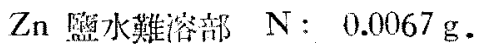

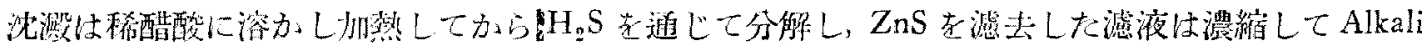

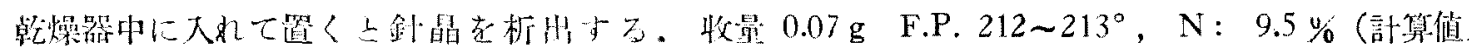
$9.5 \%)$

$\mathrm{Zn}$ 臂水易湥部 $\mathrm{N}: 0.2471 \mathrm{~g}$.

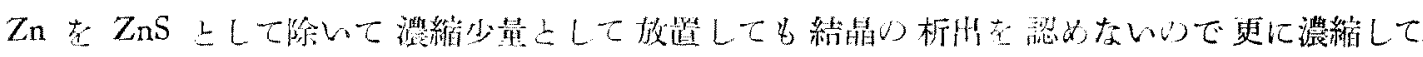

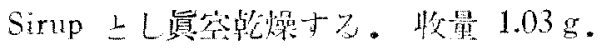

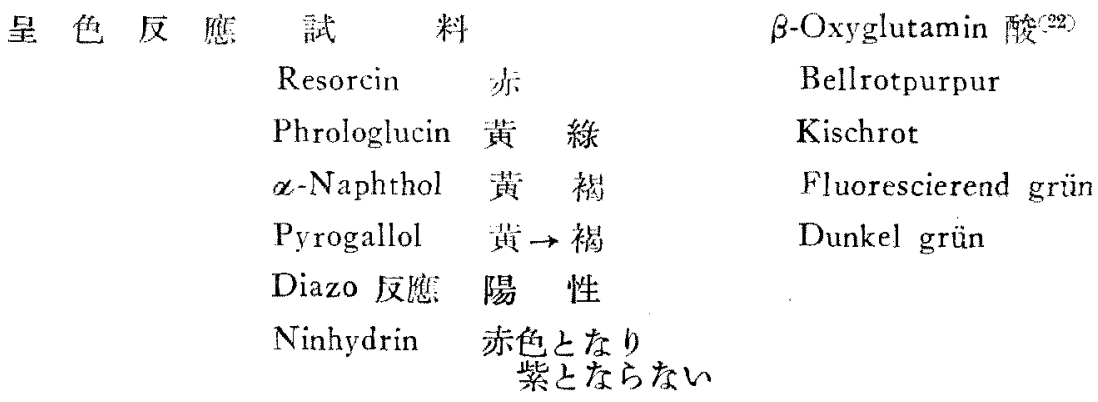

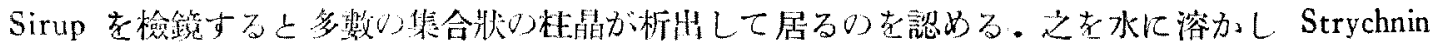

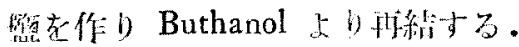

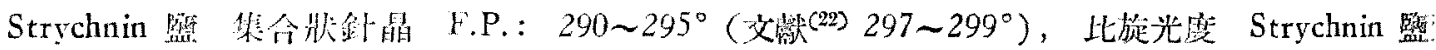

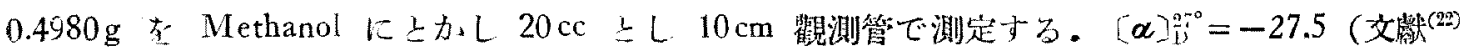
$-26.3)$.

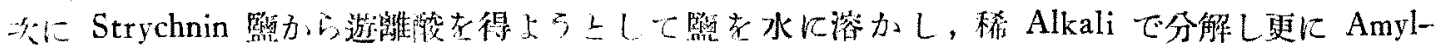




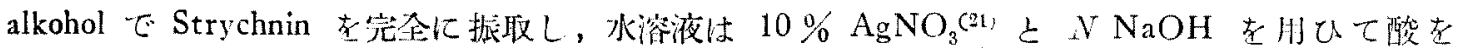

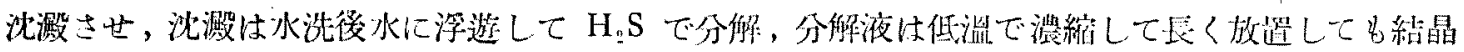

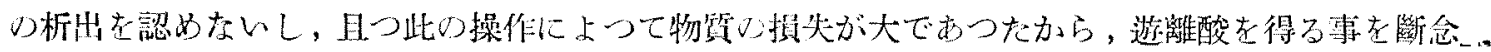

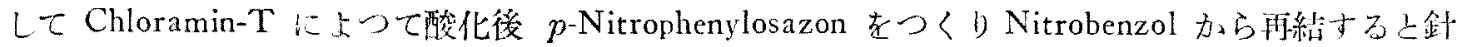

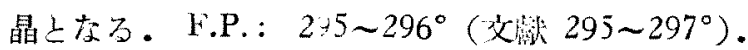

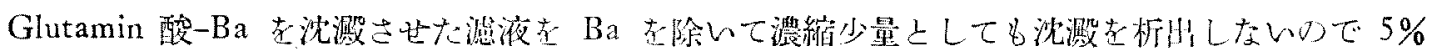

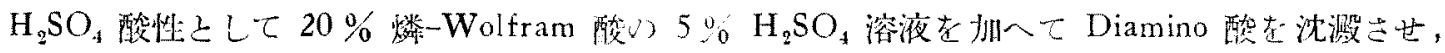
Diamino 酸區は Vickery ${ }^{(23)}$, Leavenworth 法に上り分别する。

Diamino 酸區 $\mathrm{N}: 3.1513 \mathrm{~g}$ Amino-N $9.2825 \mathrm{~g}$,

Histidin 區 $\mathrm{N}: 0.2361 \mathrm{~g}$ Monopicrolonat 收量 $1.73 \mathrm{~g}$ (Histidin $し て 0.75 \mathrm{~g}$ ), Picrolonat F.P.: $210 \sim 212^{\circ}$ (u. Z.) (文嵇 $218 \sim 220^{\circ(20)}$ ).

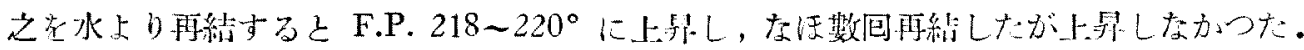

Arginin 區 $\mathrm{N}: 1.5770 \mathrm{~g}$. Flavianat 收量 $13.21 \mathrm{~g}$ (Arginin $\_し \tau 4.71 \mathrm{~g}$ ), Flavianat F.P.: 240 $\sim 250^{\circ}$ (文獻 $258 \sim 260^{\circ}$ ).

Lysin 區 $\mathrm{N}: 1.3382 \mathrm{~g}$. Lysinpikrat 收量 $16.80 \mathrm{~g}$ (Lysin として6.55g) Lysinpikrat F.P. 225

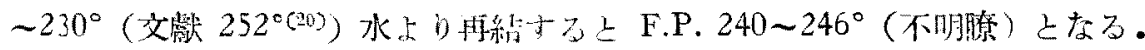

Monoamino 酸凅

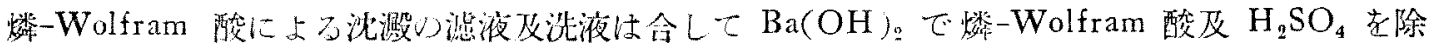
き減㕍濃綃放筧して分别沈潵させる。

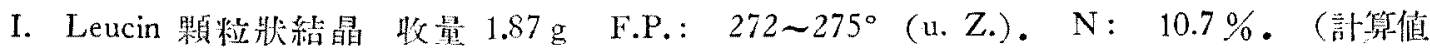
$\left.\mathrm{C}_{6} \mathrm{H}_{13} \mathrm{O}_{2} \mathrm{~N} と し \tau 10.7 \%\right), \mathrm{Cu} ， 19.5 \%$ (計算值 $\left[\mathrm{C}_{6} \mathrm{H}_{12} \mathrm{O}_{2} \mathrm{~N}\right]_{2} \mathrm{Cu} と し \tau 19.6 \%$ ), Hydantoin

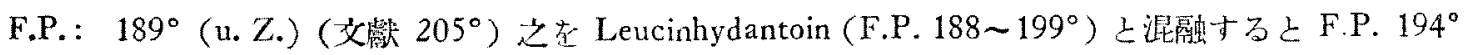
上なる。

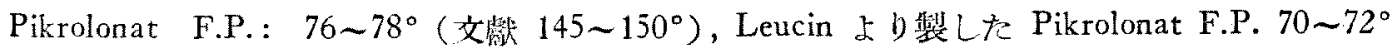
Leucin に就ての寛䮲

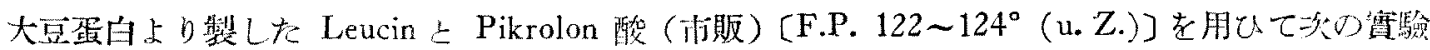
在行つた。

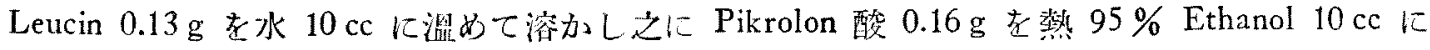

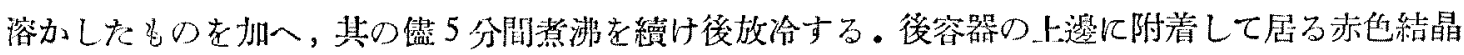
器底に析出して居る鱼色針晶之走则及に熱水加ら再結寸る。

$$
\begin{array}{lll}
\text { 赤色柱晶 } & \text { F.P.: } 70 \sim 74^{\circ} \\
\text { 黄 色針 晶 } & \text { F.P.: } 215 \sim 217^{\circ} \text { (u. Z.) }
\end{array}
$$

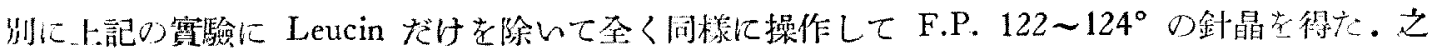
老 Pikrolon 酸之混融してb融點降下し存かつた。

II. Leucin-顆粒师絬晶 收量 $261 \mathrm{~g}$ F.P.： $240 \sim 245^{\circ}$ (u.Z.)， N: $10.1 \%$, 水上り再絬した

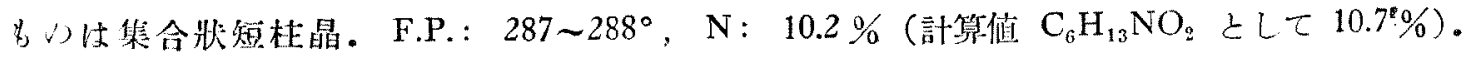
Hydantoin F.P.: $199^{\circ}$ (艾獻 205.). 


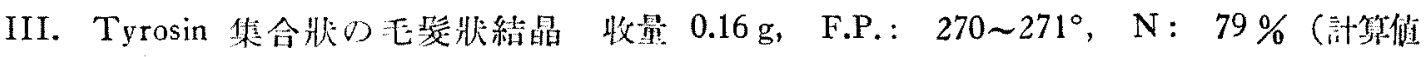

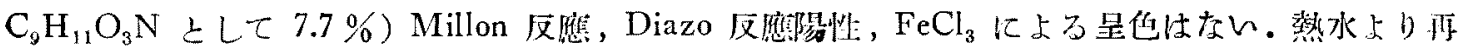
結すると F.P. 281〜282 (u. Z.) となる.

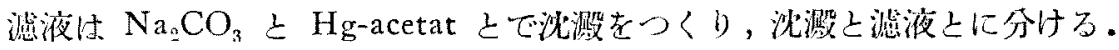

Hg-acetatに上る洮搌 N: $1.0268 \mathrm{~g}$, amino- $\mathrm{N}: 1.0144 \mathrm{~g}$.

\section{Alanin}

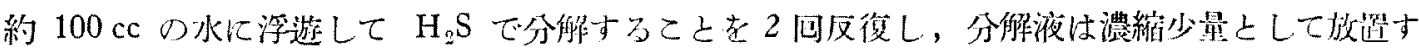
ると樹枝沜結晶老析仙する。

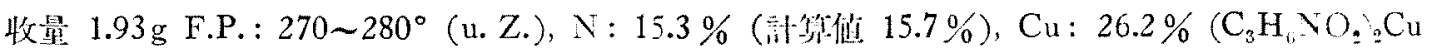
Łして $26.5 \%$ ).

水上り再絬すると鱗片秋結晶となり味がある。

II. Glykokoll

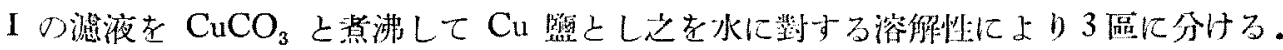

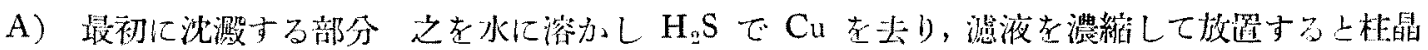

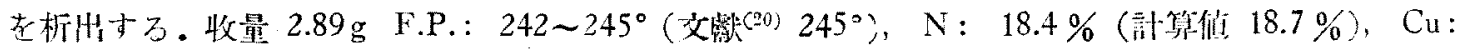
$29.2 \%$ [計算位 $\left(\mathrm{C}_{2} \mathrm{H}_{4} \mathrm{O}_{2} \mathrm{~N}\right)_{2} \mathrm{Cu}+\mathrm{H}_{2} \mathrm{O}$ Łし $29.7 \%$ ].

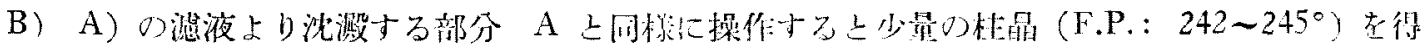
たが分析確認し得なかつた。N：0.00826g.

C) $\mathrm{N}: 0.0156 \mathrm{~g}$ 檢素しなかつた。

Hg-acetat によつて沈澱しない部分

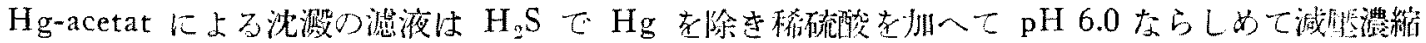

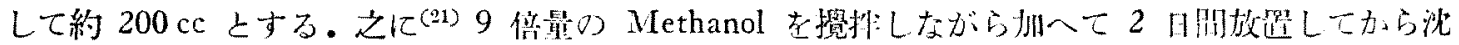
澱索吸滤し Methanol で洗㛹する。

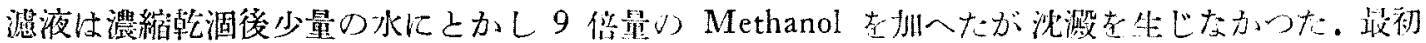
の Methanol に上る沈澱は大部分艌機物であつた。

A) Methanol に上る沈澱屁液 (Oxyprolin 區), $N: 0.5888 \mathrm{~g}$, Amino-N: $0.1133 \mathrm{~g}$.

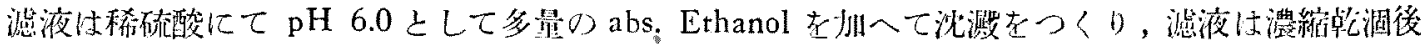

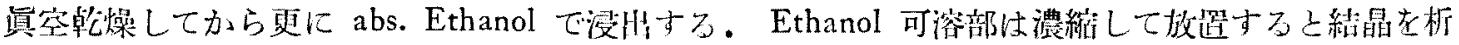

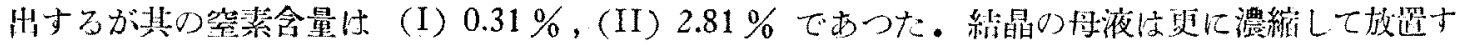

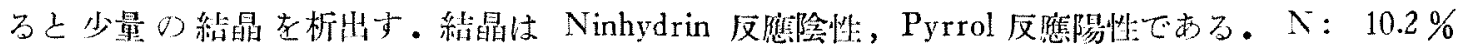

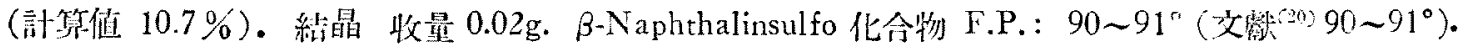

B) 絬晶母液 (Serin 區) N: $0.0+28 \mathrm{~g}$, amino- $\mathrm{N}: 0.0226 \mathrm{~g}$.

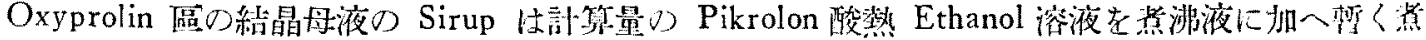
沸を續けて後放冷すると絬晶析出するが，乙のPikrolonat は分解㸃索示さないし，灰化後の灰分は Lackmus alkali 性であるので Alkalipikrolonat と認めて祫絮を中止した。

C) Methanol 易溶性銅酸 收量 $19.5 \mathrm{~g}$

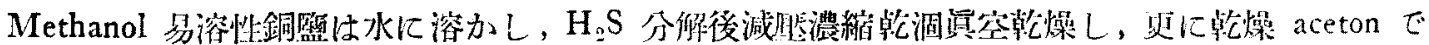


Amino 酸 收 量

\begin{tabular}{|c|c|c|c|c|c|}
\hline & & 素含 & 量 & \multirow{2}{*}{$\begin{array}{l}\text { 全慗熬 } \\
100 \text { 分 }\end{array}$} & \multirow{2}{*}{$\begin{array}{l}\text { 使凧登素 } \\
100 \text { 分 }\end{array}$} \\
\hline & (g) & 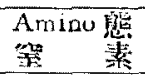 & $\begin{array}{l}\text { 非Amino 留 } \\
\text { 等 }\end{array}$ & & \\
\hline 全 毠 素 & 1.4073 & 0.4620 & 0.9453 & 12.78 & 14.48 \\
\hline Prolia 監 & 0.7463 & 0.0469 & 0.6994 & 6.73 & 7.68 \\
\hline Valin 能 & 0.6515 & \multirow[t]{2}{*}{0.4151} & 0.2364 & \multirow{2}{*}{$\begin{array}{l}5.92 \\
0.06\end{array}$} & 6.70 \\
\hline 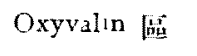 & 0.0070 & & & & 0.07 \\
\hline 损 & 0.0025 & & & 0.02 & 0.02 \\
\hline
\end{tabular}

Amino 酸收量

\begin{tabular}{|c|c|c|c|c|c|c|}
\hline & \multirow{2}{*}{$\begin{array}{c}\text { 杏素含量 } \\
\text { (g) }\end{array}$} & \multicolumn{2}{|c|}{ Amino 酸 } & \multicolumn{3}{|c|}{ 決 定 $i た$ 整素 } \\
\hline & & (g) & 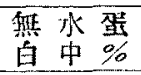 & $(\mathrm{g})$ & $\begin{array}{l}\text { 全等素 } \\
100 \text { 分的 }\end{array}$ & $\begin{array}{l}\text { 使用窒素 } \\
100 \text { 分中 }\end{array}$ \\
\hline Prolen 區 & 0.7463 & 5.27 & 7.7 & 0.64 .14 & 5.83 & 6.59 \\
\hline Valin 區 & 0.6515 & 3.31 & 4.9 & 0.3959 & 3.59 & 4.07 \\
\hline 計 & 1.3978 & 8.58 & 12.6 & 1.0373 & 9.42 & 10.66 \\
\hline 损 & & & & 0.3700 & 3.36 & 3.82 \\
\hline
\end{tabular}

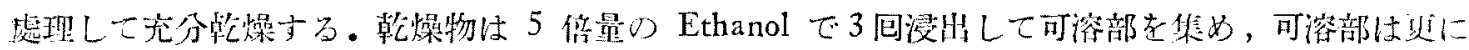

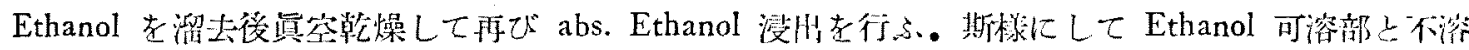
部上分ける。

C I. Ethanol 可浴部 (Prolin 區)

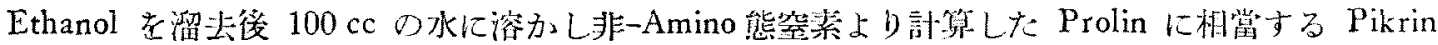

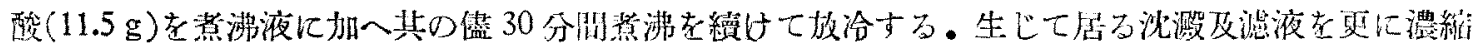
して生和る沈澱は合せて Soxhlet 沒壮器で Äther 浸出する. Prolinpikrat 收量 $15.78 \mathrm{~g}$ (Prolin 上

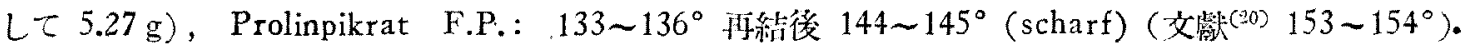

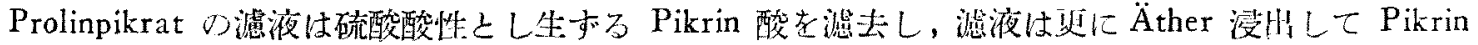

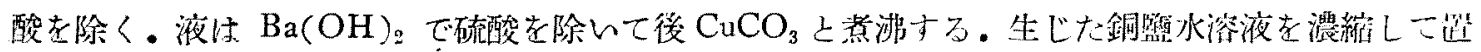

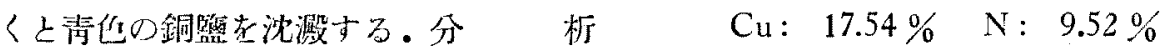

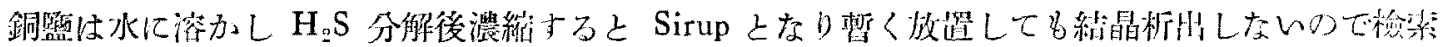
老此的。

C II. Ethanol 不溶部

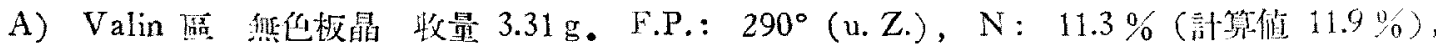
$\mathrm{Cu}: 21.3 \%$ (計算值 $\left(\mathrm{C}_{5} \mathrm{H}_{16} \mathrm{O}_{2} \mathrm{~N}\right)_{2} \mathrm{Cu} \_$乙 $21.5 \%$, Valinhydantoin F.P.: $125 \sim 127^{\circ}($ 文 龊(ㅁo $\left.124 \sim 125^{\circ}\right)$.

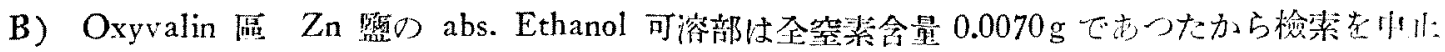


綜

括

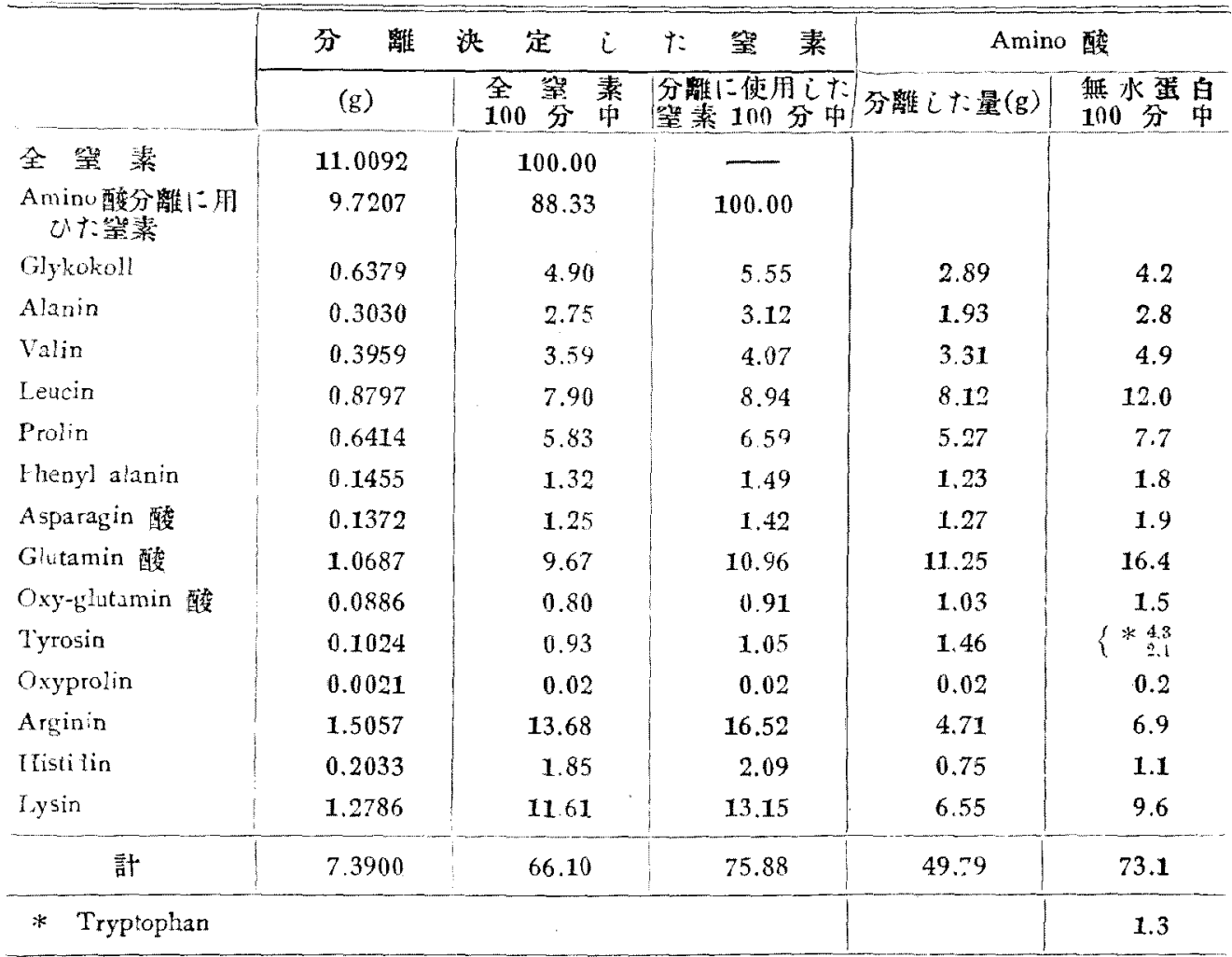

*比色法による結果

\section{考察}

1) van Slyke 法による空素分倠に就て

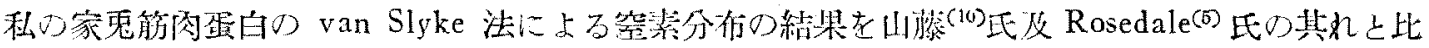

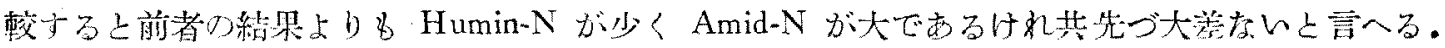

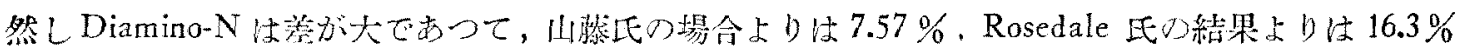

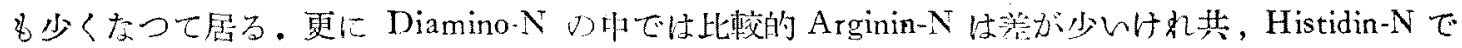
は山藤氏の場合とは $8.50 \%$ 女異つて居る。漖省の得た Histidin-Nの數値は Amino 酸分離の項に

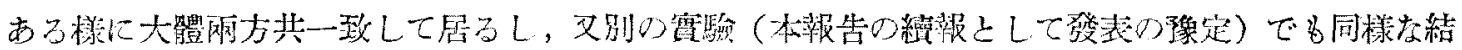

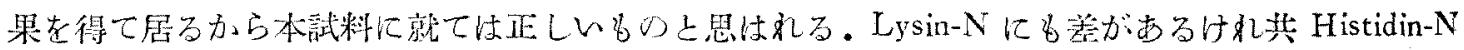

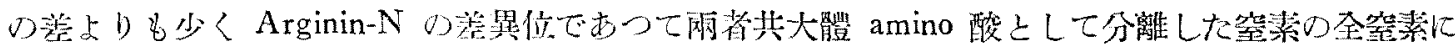

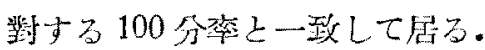

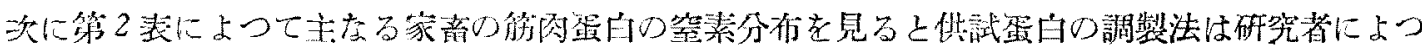

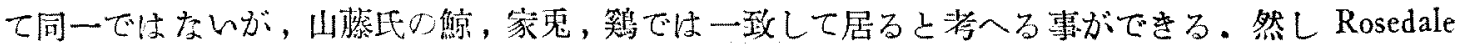

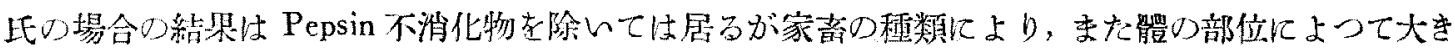

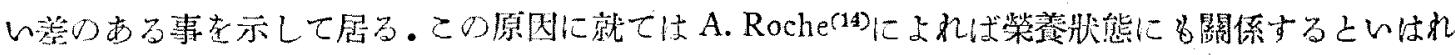

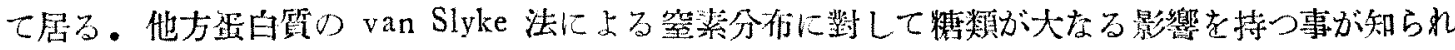
て居るが私り調製した蛋白中には當然 Glykogen が含まれて居る事が像想されるし，又多くの場合 


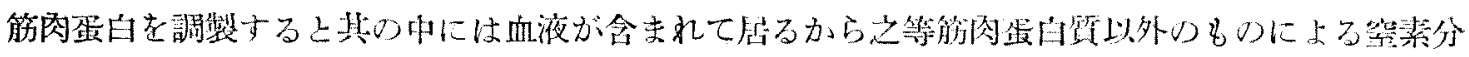

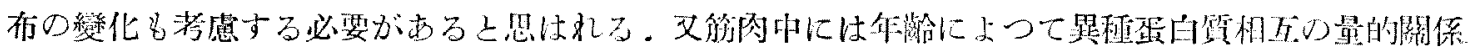

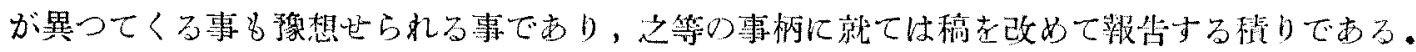

2) Brazier 法による amino 酸の分剂に就て

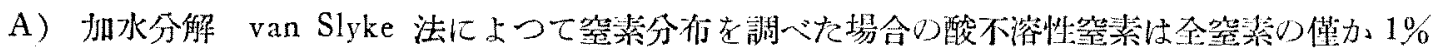

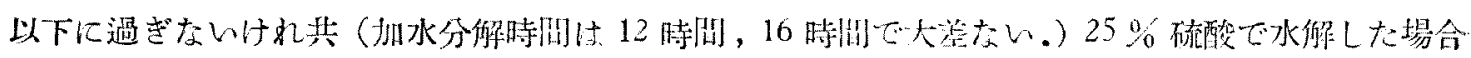

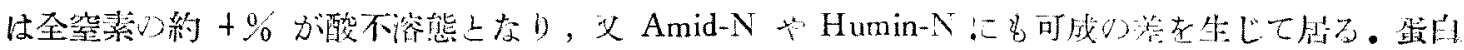

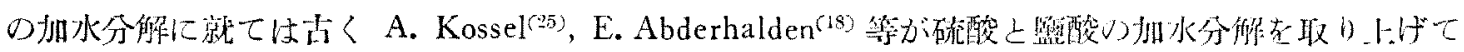

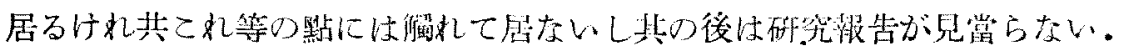

B) Amino 酸の分離に就て

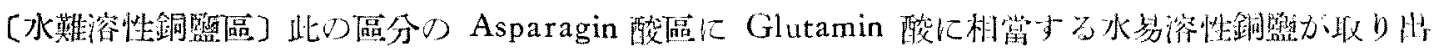

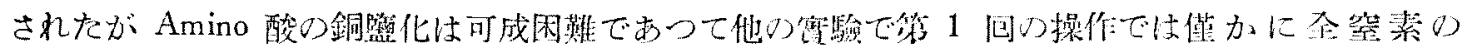

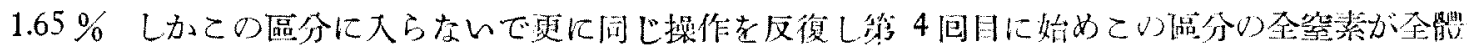

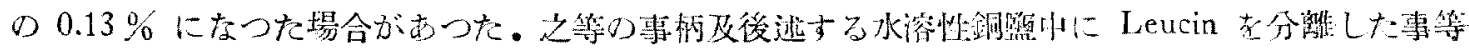
上り考へて銅辟化には深く注意する必雬がすると考へられる。

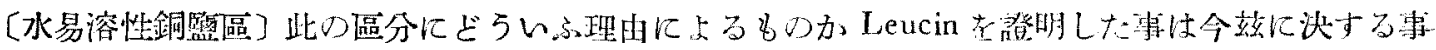
のでない事柯であつて淩日老待つて解炏し度い上䍐つて居る。

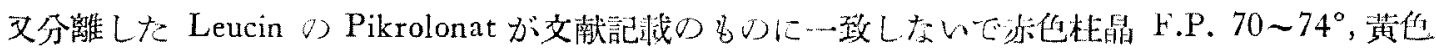

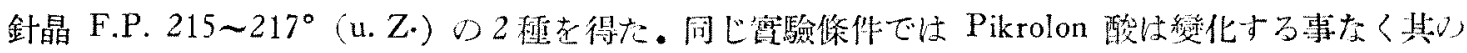

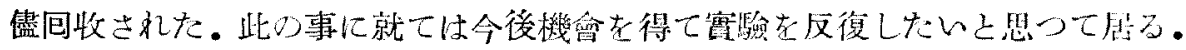

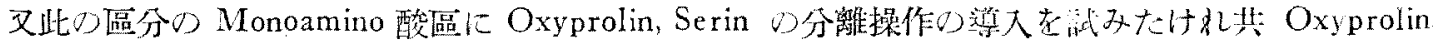

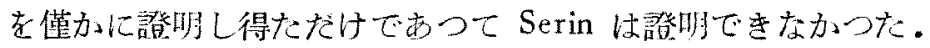

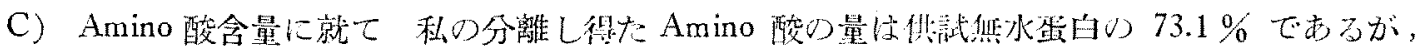

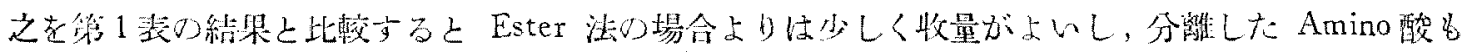

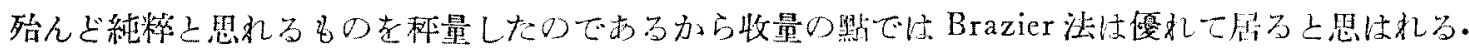

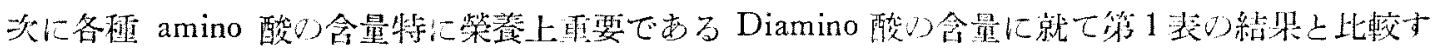
ると Lysin が少し多く, Arginin, Histidin は大體上く類似して店る. Losedale 比(5) Kossel 法

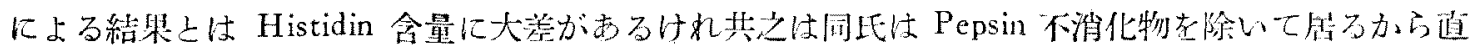
接比較する事は當を得ないであらう。

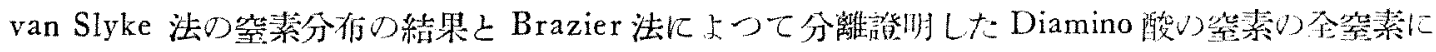

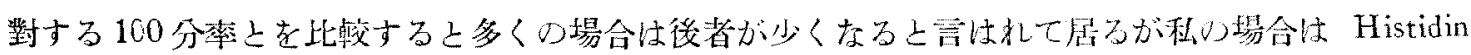
が少くなくなつただけで ArgininやLysin は少し大となつて居る。

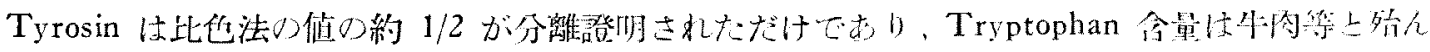
ビ等しい.

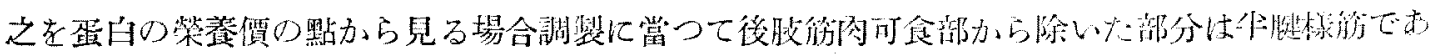

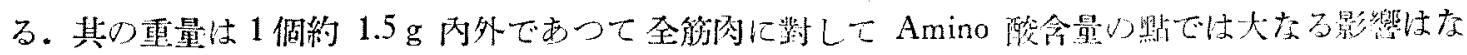

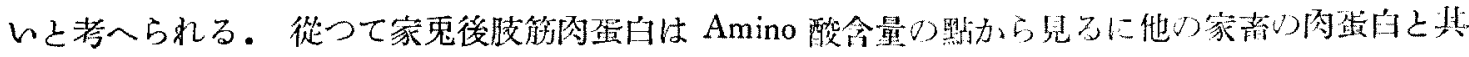

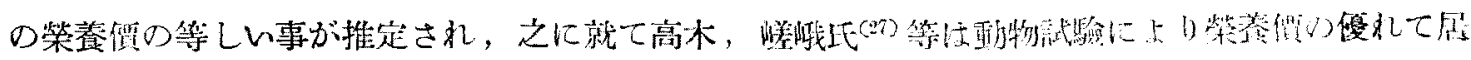


ア事在逃ベて胡る。

\section{摘 要}

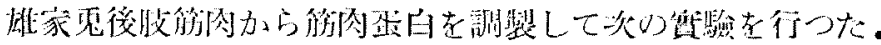

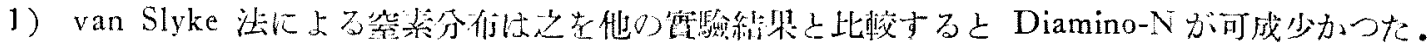

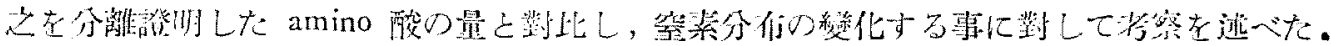

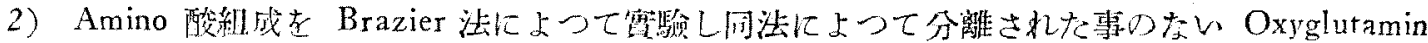

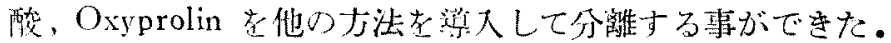

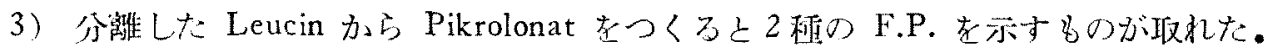

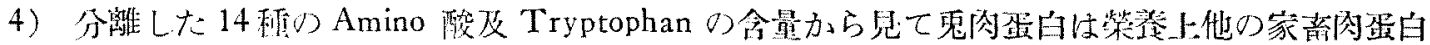
上等しい事索推道した。

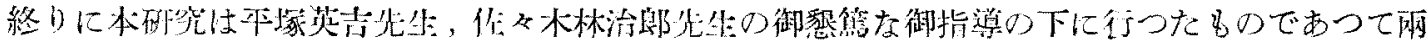

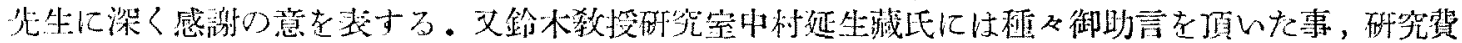

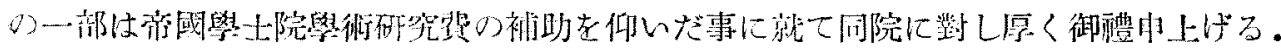

\section{引用 文 缺}

(1) 神立誠：本䓌，16，71 (昭和 15 年).

(2) Thomas R. Obborne, Frejerick W. Heyl: Amer. J. Physiol, 22, 433 C. (1908) II. 1396.

(3) Thomas B. Osborne, 1). Breese Johnes: ibid 24, 437 (1909) C. (1909) II. 1058.

(4) Juzuru Okuta, Tamazo Okimoto, Takeshi Yada: J. Cull. Agr. Tokyo Imp. Univ. 7, 29 $(1919)$.

(5) John Lewis Rosedale: Broihem. J. 16, 27 (1922).

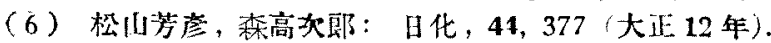

(7) D. Breese Johns, C, E, F. Gersdorff, O, Meller: J. Biul. Chem, 61, 183 (1924).

(8) Otto Fürth, Otto Deutschberger: Biochem. Z, 186, 139 (1927).

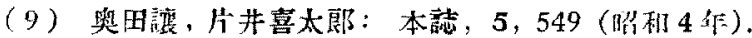

(10) 山藤一雄：學藝㒕誌，4,101 (昭和 6 年).

(11) Alfred Blankenstein, Anton Fis her: Bioshem, Z, 224, 211 (1930).

(12) Henry George Ree: Analyst 61, 160 (1936).

(13) S. Kaplansky: Z. physiol, Chem., 158, 19 (192j).

(14) A. Roche: Bull. Soc. Chim. biul. 16. 270 (1934).

(15) M. A. B. Brazier: Bio hem. J, 24, 1188. (1930).

(16) K. Pailey: Biochem. I. 31, 1396 (1937).

(17) J. W. H, Lugg: Biuchem. J. 31, 1422 (1937).

(18) E. Abderhalden, A. Weil: Z. physiol. Chem. 72, 15 (1911)

(19) G. Klein: Itantt d. Phanzenanalyse Bd. IV/1. 54, (1933)

(20) 同上: $20 \sim 33$.

(21) H. D. Dakin: J. I, ol. Chem., 44, 499 (1920).

(22（19）に同し： 55 .

(¿3) II. B. Vickery, C. S. Leavenwurth: J. Biol. C.em, 72, 403, (1927), 76, 707 (1928), 83, 528 (1929).

（24）（19）に问し： 19.

(25) A. Kossel, F. Kutscher: Z, physiol. Chem, 31, 165 (1900).

(26) F, Abderden, C. Funk: ibid, 53, 19 (1907).

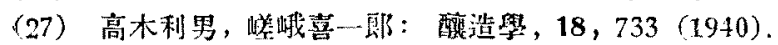

